\title{
EVALUTION EFFICENCY OF LIQUID BRADRHIZOBIUM AND AZOTOBACTER CHROOCOCCUM DSM 2286 AS CO- INOCULATION AFFECTED BY SALINITY LEVEL OF IRRIGATION WATER ON PEANUT IN SANDY SOILS OF EGYPT
}

\author{
H.M. El-Zemrany(1), G.A.A. Mekhemar(2) and S.S. Abd EI Salam(1) \\ (1) Dept. Soil Sci., Fac. Agric., Minufia University, Egypt \\ (2) Soils, Water \& Environment Inst., Rec., ARC, Egypt.
}

Received: Jul. 4, 2019

Accepted: Aug. 5, 2019

\begin{abstract}
Peanut being a leguminous crop is capable of fixing atmospheric nitrogen. The present investigation had been carried out in order to study and evaluate the efficiency of both liquid and solid inoculum of Bradyrhizobium ssp (N2-fixing bacteria) and plant growth promoting rhizobacteria (PGPR); Azotobacter chroococcum DSM 2286, as co-inoculation to decrease the negative impact of salinity levels of irrigation water on peanut plants grown in cultivated sandy soils, as well as to comparatively evaluate the responses of two peanut cultivars to the studied treatments. A pot experiment peanut seeds were inoculated with solid or liquid inoculum of Bradyrhizobium and Azotobacter chroococcum DSM 2286 (PGPR) as co-inoculation, and planted in the sandy soils. Dry weights of the growing plants yield components and oil of two peanut cultivars were determined. It was clear that the rhizospheric soil of Gregory peanut cultivar plants achieved higher values of dehydrogenase activity compared with the Giza 6 peanut cultivar plants, with the assigned experimental treatments. The inoculation treatments with Azotobacter chroococcum, as Co-inoculation, with liquid Bradyrhizobium spp of Gregory cultivar peanut plants attained a higher seed protein and oil content (\%), as compared to the other inoculation treatments.
\end{abstract}

Key words: Bradyrhizobium ssp, Azotobacter chroococcum, Peanut, Cultivar, Biofertilizer, Seed protein and oil contents, peanut cultivars, Dehydrogenase activity.

\section{INTRODUCTION}

Rhizobium, Azotobacter, Azospirillum, Flavobacterium, Pseudomonas, Arthrobacter and Bacillus are reportedly involved in osmotic adjustment, starvation resistance, and the production of polysaccharide products for binding $\mathrm{Na}^{+}$in the rhizosphere to enhance salinity tolerance in plants (Chaudhary and Sindhu, 2015).

Use of PGPB is a safe and eco-friendly choice for environmental management and better agricultural practices. Several important aspects of plant metabolism are adversely affected by the level of soil salinity which results in significant reduction of productivity, yield and nutrients status (Tank and Saraf, 2010). Therefore, to enhance the global crop productivity, it is very important to work on biological means of salinity stress mitigation.

Salinity is one of the most severe environmental stresses in current scenario that causes imbalance and reduction in growth and productivity of crops cultivated in arid and semi-arid regions (Numan et al., 2018). Globally, huge areas of saline lands are reported which severely affects the nutrient status of soil and crop productivity.

Peanut (Arachis hypogaea L.) is one of the most important leguminous crops, is due to the high nutritive value of its 
seeds which is considered rich in protein $(30 \%)$, oil $(38-50 \%), 20 \%$ carbohydrates and $5 \%$ fiber (Fageria et al., 1997). Moreover, the peanut vines (contain more than $10 \%$ protein) is another advantage of the crop as a good fodder for livestock. In Egypt; peanut occupied about 80000 hectare in 2017 which produced about 300,000 tons unshelled seeds (FAO Yearbook, 2017).

The increasing of salinity phenomenon of the artesian wells used to irrigate the agricultural crops in the newly reclaimed desert lands in Egypt attracted the attention to investigate the ability of liquid inoculum of Bradyrhizobium spp ( $\mathrm{N}_{2}$-fixing bacteria) and plant growth promoting rhizobacteria (PGPR) as co-inoculation to decrease the negative impact of salinity of irrigation water on peanut plants grown in sandy soils. In this study two selected cultivars of a peanut were selected and inoculated individually with solid and liquid inoculum of Bradyrhizobium without or with Azotobacter chroococcum DSM 2286 (PGPR) and planted in the newly reclaimed sandy soil. After plant harvesting, dehydrogenase activity, dry weights of the growing plants (shoots and seeds weights per plant) as well as seed oil and protein content, were determined.

\section{MATERIALS AND METHODS Layout}

The present investigation had been carried out at a pot experiment in order to evaluate the efficiency of both liquid and solid inoculum of Bradyrhizobium spp alone or with plant growth promoting rhizobacteria "PGPR" (Azotobacter chroococcum DSM 2286) of two peanut (Arachis hypogaea L.) cultivars i.e. Giza 6 and Gregory irrigated by saline water at different levels under sandy soil condition.

\section{Materials}

1. Soil

Surface $(0-30 \mathrm{~cm})$ soil samples of cultivated sandy soil were collected from Sadat City Minoufia Governorate, Egypt; air-dried, ground, mixed well and sieved through a $2 \mathrm{~mm}$ - sieve. The sieved soils were subjected to initial analyses for some physical and chemical properties and its contents of some macronutrients as described by Klute, 1986 and Cottenie et al., 1982, the obtained data are presented in Table (1).

\section{Irrigation water}

Two sources of groundwater of artesian well of Sadat City varied in the salinity level, i.e. 1000 and $2000 \mathrm{mg} \mathrm{L}^{-1}$ for the first and second artesian water (W2 and $\mathbf{W} 3$ ), respectively. In addition, Nile water (W1) of Bahre Shibine El Kom (563 $\mathrm{mgL}^{-1}$ ) Minoufia Governorate was used in this study as a control. Data of chemical analyses of those irrigation water, which carried out according to Cottenie et al. (1982) and the obtained data are shown in Table (2).

\section{Peanut seeds}

Two peanut (Arachis hypogaea L.) cultivars i.e. Giza 6 cv (local hybrid) and Gregory; developed by North Carolina State University and Virginia Tech breeding programs were kindly provided from Field Crop Research Institute, Agriculture Research Center (ARC), Giza, Egypt.

\section{Bacterial strains}

- Bardyrhizobium spp. (strain USDA 3456), one bag of Oqadine (as solid inoculants) was kindly obtained from the Biofertilizers Production Unit, Agric. Microbiology, Dept., Soils, Water and Environ. Res. Inst. (SWERI), Agric. Res. Center (ARC), Giza, Egypt. - Azotobacter chroococcum DSM 2286, from bank strains of Laboratory Soil Microbiology, Department of Soil Science, Faculty of 
Agriculture, Menoufia University, originally isolated from the salt affected soil of Wadi El Natroon, Beheira Governorate, it's having higher survival capabilities at different salinity levels, relatively higher potentials of nitrogenase activity, and $P$ solubilization capacity, and IAA (Indole Acetic Acid) production. This strain had been short listed from a collection of over 150 isolates of rhizobacteria based on its salt tolerance. The strain was previously defined by genotypic identification which performed by amplification and partial nucleotide sequencing of the 16s rihbosomal DNA (16s rDNA) (El Zemrany et al., 2015).

Table (1): Some physical and chemical properties of the experimental soil.

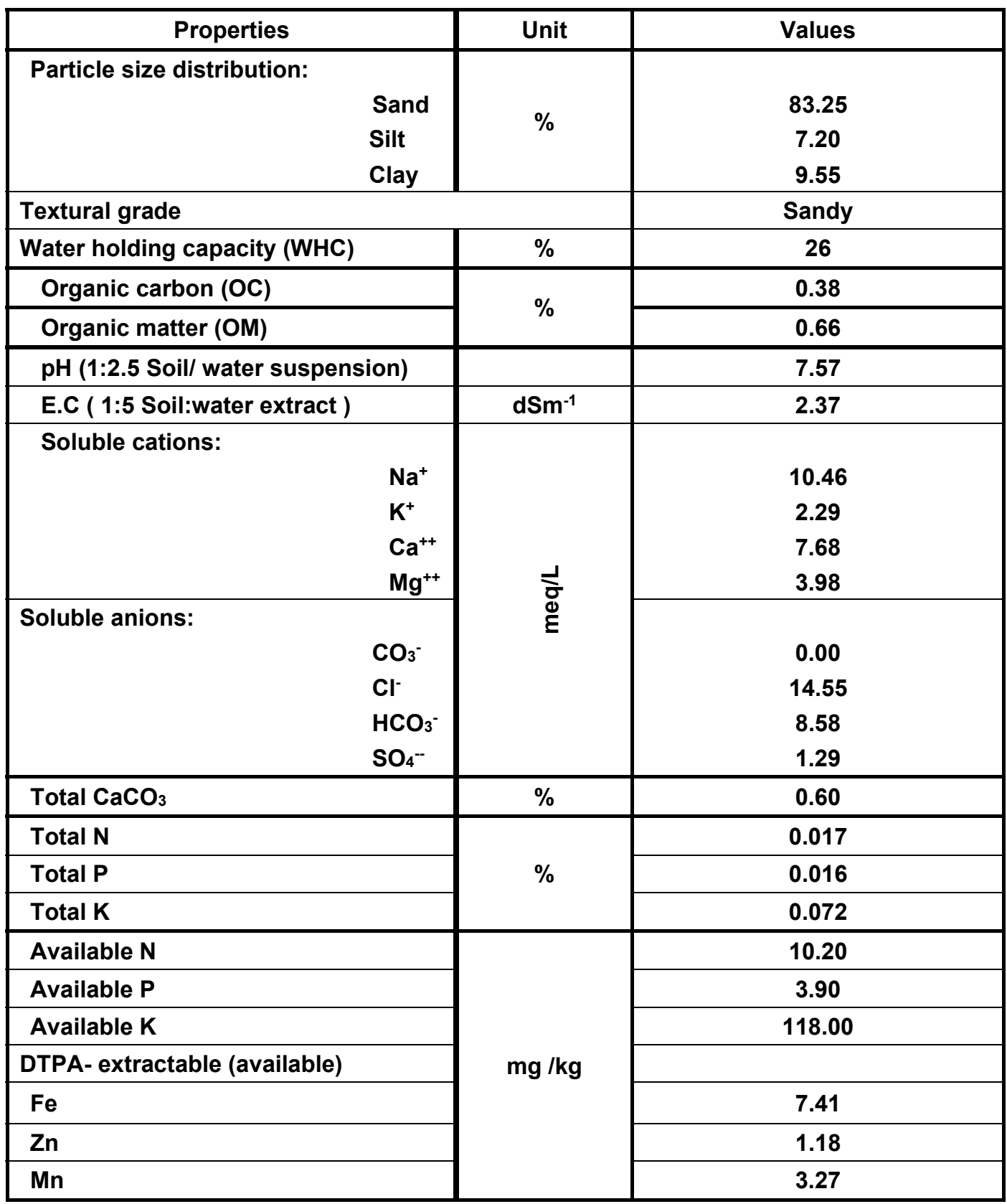


H.M. El-Zemrany, et al.,

Table (2): Some chemical properties of the analyzed used irrigation water resources.

\begin{tabular}{|c|c|c|c|c|c|c|c|c|c|c|c|}
\hline \multirow{2}{*}{$\begin{array}{c}\text { Irrigation } \\
\text { water sources }\end{array}$} & \multirow[b]{2}{*}{$\mathrm{pH}$} & \multirow[b]{2}{*}{ TDS } & \multirow[b]{2}{*}{ EC } & \multicolumn{4}{|c|}{ Cations } & \multicolumn{3}{|c|}{ Anions } & \multirow[b]{2}{*}{ SAF } \\
\hline & & & & $\mathrm{Ca}^{2+}$ & $\mathrm{Mg}^{2+}$ & $\mathrm{Na}^{+}$ & $\mathrm{K}^{+}$ & $\mathrm{Cl}^{-}$ & $\mathrm{HCO}^{-}$ & $\mathrm{SO}_{4}^{2}$ & \\
\hline & & $\mathrm{mgL}^{-1}$ & $\mathrm{dSm}^{-1}$ & \multicolumn{8}{|c|}{ meq $L^{-1}$} \\
\hline Nile river (W1) & 7.32 & 563 & 0.88 & 3.04 & 1.24 & 2.64 & 0.72 & 1.74 & 4.18 & 1.70 & 1.80 \\
\hline $\begin{array}{l}\text { Artesian well } \\
\text { water No } 1 \\
\text { (about } 1000 \\
\text { mg/L) (W2) }\end{array}$ & 7.69 & 1030 & 1.61 & 4.74 & 1.81 & 6.28 & 1.23 & 3.29 & 6.08 & 4.70 & 3.47 \\
\hline $\begin{array}{l}\text { Artesian well } \\
\text { water No } 2 \\
\text { (about } 2000 \\
\text { mg/L) (W3) }\end{array}$ & 7.82 & 2073 & 3.24 & 9.31 & 3.76 & 12.94 & 2.70 & 8.72 & 12.45 & 7.54 & 5.06 \\
\hline
\end{tabular}

\section{Preparation of liquid inoculants}

Bardyrhizobium was cultured in yeast extract mannitol broth medium (Vincent, 1970). Cultures were incubated at $28{ }^{\circ} \mathrm{C}$ for three days on a rotary shaker until early log phase to ensure population density of $10^{8} \mathrm{cfu} / \mathrm{ml}$ culture.

\section{Preparation of Azotobacter chrococoum (PGPR) inoculum}

Azotobacter chrococoum DSM 2286

was grown in King's medium (Atlas, 1995). Cultures were incubated at $28{ }^{\circ} \mathrm{C}$ for three days on a rotary shaker until early log phase to ensure population density of $10^{9} \mathrm{cfu} / \mathrm{ml}$ culture.

\section{Greenhouse Experiment.}

A greenhouse experiment was carried out as a pot experiment during summer grown season of 2016 at the period of 28 April to 7 September in the greenhouse of Soil Science Department, Faculty of Agriculture, Shbin EI Kom, Menoufia University. The studied treatments were arranged randomly in a split randomized block design system with six replicates. A180 plastic pots which $30 \mathrm{~cm}$ inner diameter and $\mathbf{4 0} \mathrm{cm}$ depth were used in this study. Each pot was filled by $10 \mathrm{~kg}$ of prepared and characterized sandy soil. These pots were divided into five main groups (36 pots for each main group) representing biofertilization i.e. the liquid, solid Bradyrhizobium, liquid Bradyrhizobium + Azotobacter chrococoum, solid Bradyrhizobium + Azotobacter chrococoum and without any biofertilizers inoculation treatments as follows:

1- Control treatments (without any biofertilizers inoculation) (36 pots).

2- Inoculation by solid Bradyrhizobium only (36 pots).

3- Inoculation by liquid Bradyrhizobium only (36 pots).

4- Co-inoculation: by solid Bradyrhizobium fertilization + PGPR (Azotobacter chrococoum) (36 pots). 
5- Co-inoculation: by liquid Bradyrhizobium fertilization + PGPR (Azotobacter chrococoum) (36 pots).

The pots of each main group were divided into three sub-groups representing the three salinity levels of irrigation water i.e. W1, W2 and W3 (12 pots for each salinity levels). These subgroups were divided into two sub-sub groups representing two peanut cultivars namely; Giza 6 and Geregory (6 pots for each peanut cultivar), the soil water content was adjusted to $70 \%$ of the water holding capacity (WHC). Each pot was planted by five seeds, where the plants of each pot were thinned to 3 plants after 14 days of planting. Where, each seed received $1 \mathrm{ml}$ (about $10^{8} \mathrm{cfu}$ seed $^{-1}$ ) of liquid inoculm of Azotobacter chrococoum, for 4 times: immediately after sowing directly, and 7, 15 and 21 days after sowing, in all treatments of Coinoculation by PGPR. Also, before planting all pots were fertilized by ordinary calcium superphoshate $(6.8 \% \mathrm{P})$ at a rate of $60 \mathrm{~kg} \mathrm{fedd}^{-1}\left(6 \mathrm{~g} \mathrm{pot}^{-1}\right)$ and good mixed. Potassium sulphate (50\% $\mathrm{K}_{2} \mathrm{O}$ ) was added as $\mathrm{K}$ fertilizer at a rate of $100 \mathrm{~kg} \mathrm{fedd}^{-1}\left(10 \mathrm{~g} \mathrm{pot}^{-1}\right)$ in two equal doses before sowing and after 21 days of planting. In addition, ammonium nitrate (33\% $\mathrm{N}$ ) as $\mathrm{N}$ fertilizer was added at a rate of $50 \mathrm{~kg} \mathrm{fedd}^{-1}\left(5 \mathrm{~g} \mathrm{pot}^{-1}\right)$ after 15 and 30 days of sowing. Both $K$ and $N$ treatments were carried out with irrigation water.

After $\mathbf{7 5}$ days of sowing, the plants of three replicates (9 plants) for each treatment were taken as a whole. The plants of each replicate were leached generally using tap water to remove the soil particles. The plant materials air dried and oven dried at $70{ }^{\circ} \mathrm{C}$ for $72 \mathrm{hrs}$. and weighed to determine the dry matter yield of roots and shoots. At harvest (130 days after sowing) the plants of other three replicates of each treatment were taken as a whole to determine protein and seed oil (\%) content.

- Seed oil percentage: the soxhelt continuous extraction apparatus with petroleum ether $\left(40-60{ }^{\circ} \mathrm{C}\right)$ as an organic solvent was used to determine the seed oil percentage according to AOAC (2000).

- Seed protein content (\%): the crude protein was calculated by multiple the nitrogen concentrations $(\%)$ by 6.25 (AOAC, 2000).

\section{Biochemical Assay:}

- Dehydrogenase activity was determined colourimetrically, for the 2,3,5- triphenyl formazan (TPF) produced from the reduction of 2,3,5- triphenyl tetrazolium chloride (TTC), using acetone for extraction according to Skujins (1976). In this concern the colorless TTC is changed to red colored (TPF) or tris phenyl formazan.

\section{Data Recorded}

Raw results (analytical data of the replicates means of the various subtreatments) were further calculated on the dry weight basis of the plants, as follows:

1- Dry weight (g plant $\left.{ }^{-1}\right)$.

2. Dehydrogenase activity (DHA) $\mu \mathrm{g}$

formazan $\mathrm{g}^{-1}$ soil hour ${ }^{-1}$.

3. Protein content (\%).

4. Oil content (\%).

- Relative changes "RC\%" of the obtained data

Rates of the relative changes "RC\%" of the final results (as percent) were calculated for the result tabulated for a particular sub-treatment, referring to the result of the specific control (without bifertilizers).

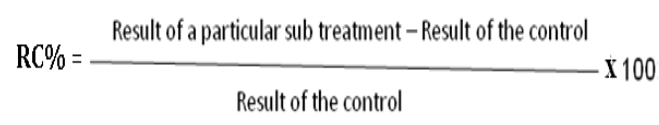


Statistical Analysis

Analysis of variance (ANOVA) and

L.S.D test were applied to analyze the obtained results statistically, according to Steel and Torrie (1980).

\section{RESULTS AND DISCUSSION}

1. Dry matter yields (DMY) of rots and shoot peanut plants.

Data in Table 3 demonstrated that, all inoculation treatments with solid or liquid Bradyrhizobium alone or with $A$. chroococcum as co-inoculation significantly augmented the dry matter yields (DMY) of the two cultivar peanut plants i.e. Giza 6 and Gregory, as compared to the uninculated one, under the three salinity levels of irrigation water i.e. W1, W2 and W3. These data pointed out that, application of biofertilizers increased DMY of root and shoot peanut plants especially with the treatments of Bradyrhizobium $+A$. chroococcum more than the inoculation with the solid or liquid Bradyrhizobium alone. With the application of biofertilizers, the obtained DMY of root and shoot peanut plants irrigated with the Nile water (W1) were significantly higher than those received the others salinized water at levels, 1000 (W2) and 2000 (W2) $\mathrm{mg} \mathrm{L}^{-1}$. The maximum values of DMY of plant shoots were; 12.46, 10.90, $9.64 \mathrm{~g} \mathrm{plant}^{-1}$, for Giza 6 cultivar peanut plant, irrigated with the three salinity levels of water W1, W2 and W3 with liquid Bradyrhizobium $+A$. chroococcum treatments. While, it were; 13.39, 11.41 and $10.52 \mathrm{~g} \mathrm{plant}^{-1}$, for Gregory cultivar peanut plant, treated with the same water of W1, W2 and W3, respectively, at the same inoculation treatments. This could be due to the essential role of Bradyrhizobium in enhancing plant growth and $\mathrm{N}_{2}$-fixation as reported by Mekhemar et al. (2007).
Data in Table 3 revealed that, Gregory cultivar peanut plant gained the significantly highest mean values root and shoot DMY as compared to the cultivar of Giza 6, under the all treatments study. Also, the data in Table 3 indicated that, the root DMY results of the both peanut cultivars plants, exactly matched with the dry weight of plant shoots, for all inoculation treatments, under the same salinity levels of irrigation water.

The relative changes $R C$ of root and shoot DMY affected by the all of inoculation treatments, at the same salinity levels of irrigation water, of the two peanut cultivars plants, illustrated in Table (3) revealed that, the inoculations treatments of solid or liquid Bradyrhizobium $+A$. chroococcum treatments, had a higher positive RC of root and shoot DMY, at the same salinity levels of irrigation water for both peanut cultivars plants. However, the plants inoculated with liquid Bradyrhizobium $+A$. chroococcum treatments, induced a higher RC values of shoot DMY, of the Giza 6 peanut cultivar plants, with the treatments of $2000 \mathrm{mg} \mathrm{L}^{-1}$ (W3) of irrigation water. Whereas, the plants inoculated with liquid Bradyrhizobium + $A$. chroococcum treatments, received the higher salinity level, $2000 \mathrm{mg} \mathrm{L}^{-1}$ (W3), of the Gregory peanut cultivar plants, attained a higher "RC values of root DMY. These results are in the same line with those obtained by Abdel-Wahab et al. (2008) and Verma et al. (2010). This could be due to the essential role of Bradyrhizobium in enhancing plant growth and $\mathrm{N}_{2}$-fixation as reported by Mekhemar et al. (2007). The promotion effect of PGPR's on plant activity has been reported by many investigators (Tilak et al., 2005 and Yadav et al., 2014). 
Evalution efficency of liquid bradrhizobium and azotobacter

Table (3): Dry matter yields (DMY) $\left(\right.$ g plant $^{-1}$ ) and its relative change (RC) of both roots and shoots of Giza 6 and Gregory peanut cultivars as affected by inoculation and salinity levels of irrigation water (W1, W2 and W3), at 75 old day.

\begin{tabular}{|c|c|c|c|c|c|c|c|c|c|}
\hline \multirow{4}{*}{$\begin{array}{l}\text { Inoculation } \\
\text { treatments }\end{array}$} & \multirow{4}{*}{ 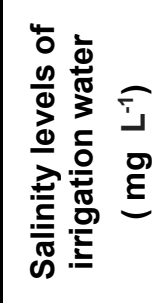 } & \multicolumn{4}{|c|}{ Roots dry matter } & \multicolumn{4}{|c|}{ Shoots dry matter } \\
\hline & & \multicolumn{8}{|c|}{ Peanut Cultivars } \\
\hline & & \multicolumn{2}{|c|}{ Giza 6} & \multicolumn{2}{|c|}{ Gregory } & \multicolumn{2}{|c|}{ Giza 6} & \multicolumn{2}{|c|}{ Gregory } \\
\hline & & $\underset{\text { plant }^{-1}}{\mathbf{g}}$ & $\begin{array}{l}\text { RC } \\
(\%)\end{array}$ & $\underset{\text { plant }^{-1}}{\text { g }}$ & $\begin{array}{l}\text { RC } \\
(\%)\end{array}$ & $\underset{\text { plant }^{-1}}{\text { g }}$ & $\begin{array}{l}\text { RC } \\
(\%)\end{array}$ & $\underset{\text { plant }^{-1}}{\mathbf{g}}$ & $\begin{array}{l}\text { RC } \\
(\%)\end{array}$ \\
\hline \multirow{3}{*}{ Control } & Nil water & 1.01 & 0.00 & 1.15 & 0.00 & 6.59 & 0.00 & 7.61 & 0.00 \\
\hline & 1000 & 0.90 & 0.00 & 1.03 & 0.00 & 5.68 & 0.00 & 6.49 & 0.00 \\
\hline & 2000 & 0.81 & 0.00 & 0.87 & 0.00 & 4.89 & 0.00 & 5.71 & 0.00 \\
\hline \multicolumn{2}{|c|}{ Mean } & 0.91 & & 1.02 & & 5.72 & & 6.60 & \\
\hline \multirow{3}{*}{$\begin{array}{l}\text { Solid } \\
\text { Brady }\end{array}$} & Nil water & 1.30 & 28.99 & 1.48 & 28.94 & 8.82 & 33.79 & 9.38 & 23.25 \\
\hline & 1000 & 1.19 & 32.01 & 1.31 & 27.18 & 7.53 & 32.53 & 8.52 & 31.35 \\
\hline & 2000 & 1.05 & 29.94 & 1.09 & 25.66 & 6.08 & 24.38 & 7.29 & 27.62 \\
\hline \multicolumn{2}{|c|}{ Mean } & 1.18 & & 1.29 & & 7.48 & & 8.40 & \\
\hline \multirow{3}{*}{$\begin{array}{l}\text { Liquid } \\
\text { Brady }\end{array}$} & Nil water & 1.56 & 54.88 & 1.82 & 57.89 & 9.72 & 47.44 & 11.05 & 45.21 \\
\hline & 1000 & 1.35 & 50.41 & 1.58 & 53.48 & 8.45 & 48.70 & 9.92 & 52.89 \\
\hline & 2000 & 1.20 & 48.54 & 1.35 & 55.19 & 7.18 & 46.81 & 8.43 & 47.56 \\
\hline \multicolumn{2}{|c|}{ Mean } & 1.37 & & 1.58 & & 8.45 & & 9.80 & \\
\hline Solid & Nil water & 1.91 & 89.15 & 2.2 & 91.51 & 10.75 & 63.18 & 12.22 & 60.58 \\
\hline \multirow[t]{2}{*}{ Brady+Azo } & 1000 & 1.64 & 82.66 & 1.91 & 85.22 & 9.57 & 68.45 & 10.69 & 64.68 \\
\hline & 2000 & 1.44 & 78.16 & 1.62 & 86.76 & 8.56 & 75.05 & 9.16 & 60.38 \\
\hline \multicolumn{2}{|c|}{ Mean } & 1.66 & & 1.91 & & 9.63 & & 10.69 & \\
\hline \multirow{3}{*}{$\begin{array}{c}\text { Liquid } \\
\text { Brady+ } \\
\text { Azo }\end{array}$} & Nil water & 2.06 & 104.4 & 2.4 & 108.6 & 12.46 & 89.04 & 13.39 & 75.92 \\
\hline & 1000 & 1.79 & 99.34 & 2.12 & 105.4 & 10.9 & 91.85 & 11.41 & 75.82 \\
\hline & 2000 & 1.58 & 95.45 & 1.85 & 112.3 & 9.64 & 97.17 & 10.52 & 84.3 \\
\hline \multicolumn{2}{|c|}{ Mean } & 1.81 & & 2.12 & & 11.00 & & 11.77 & \\
\hline \multicolumn{10}{|c|}{ L.S.D. at 0.05 for treatments of: } \\
\hline \multicolumn{2}{|c|}{ Inoculation } & \multicolumn{4}{|c|}{0.053} & \multicolumn{4}{|c|}{0.382} \\
\hline \multicolumn{2}{|c|}{ Irrigation Water } & \multicolumn{4}{|c|}{0.041} & \multicolumn{4}{|c|}{0.296} \\
\hline \multicolumn{2}{|l|}{ Cultivars } & \multicolumn{4}{|c|}{0.033} & \multicolumn{4}{|c|}{0.242} \\
\hline
\end{tabular}


Data in Tables (3) indicated that, the inoculation treatments with both Bradyrhizobium individually or with PGPR (Co- inoculation, A. chroococcum) were able to mitigate the adverse effects of salinity stress of irrigation water up to $2000 \mathrm{~g} \mathrm{~L}^{-1}$ (W3), on both cultivars of peanut plants. These results agreed with other investigators of Lopez-Gomez et al. (2014a and b) and Kang et al. (2015), who reported that microorganisms are beneficial to plants, secrete metabolites that solubilize the complex organic substances into simpler forms making them easily available to plants, enhance plant growth, and protect plants from diseases and other abiotic stresses. In particular, bacterial synthesis of aminocyclopropane-1-carboxylate (ACC) deaminase, exopolysaccharides, indole3-acetic acid (IAA), gibberellins (Gas), hydrogen cyanide (HCN), proline, nodulation factors,5-aminolevulinic acid, and siderophores, as well as the ability for phosphate and potassium solubilization, nitrogen fixation, and ammonia production in bacteria can increase the salt stress tolerance in plants have been identified and documented as having the capacity to mitigate the toxic effects of salinity stress in plants (Kang et al., 2014b; Nunkaew et al., 2014; Munoz et al., 2014 and Palaniyandi et al., 2014). AbdelWahab et al. (2008) and Badawi et al. (2011) reported that co-inoculation with Rhizobium and PGPR gave the highest values of shoots dry weight.

Bacteria producing phytohormones (IAA and GA) transport their metabolites to roots and enhance plant growth. IAA content in plant cells decreases under salt stress, resulting in stomatal closure (Dunlap and Binzel, 1996) and disrupts cell wall plasticity and cell wall extension (Ribaut and Pilet, 1994). IAA-producing bacteria stimulate the endogenous IAA synthesis and compensate for the saltinduced reduction of IAA in plants (Liu et al., 2013).

\section{Microbiological Parameter}

Dehydrogenase activity "DHA" in soil.

Dehydrogenase activity (DHA) is frequently used as a measurement of the overall microbial activity in soil. Data reported in Table (4) display the values of dehydrogenase activity ( $\mu \mathrm{g}$ formazan $\mathrm{g}^{-1}$ soil hour ${ }^{-1}$ ) and its RC, \%, in the rhizospheric soil of Giza 6 and Gregory cultivars peanut plants, at $\mathbf{7 5}$ days after sowing, as affected by inoculation treatments, irrigated with the three salinity levels of water i.e. W1, W2 and W3. Results pointed out that dehydrogenase activity in the rhizospheric soil of peanut plants significantly increased with all inoculation treatments more than the uninoculated one. The co-inoculation treatments with Azotobacter chroococcum DSM 2286 with solid or liquid Bradyrhizobium ssp. induced significantly increases of the "DHA" than those solid or liquid Bradyrhizobium spp, alone, received the three salinity levels of irrigation water. Whereas, the first salinity level of irrigation water (Nile water), appeared the most positively effect on the both peanut cultivars inoculated with the different treatments. The rhizospheric soil of Gregory peanut cultivar plants attained significantly higher values of dehydrogenase activity compared with the Giza 6 peanut cultivar plants, with the assigned experimental treatments. 
Table (4): Dehydrogenase activity in the rhizospheric soil of Giza 6 and Gregory cultivars peanut plants, and their relative changes values $\mathrm{RC}$, at 75 days after sowing, as affected by inoculation and salinity levels of irrigation water.

\begin{tabular}{|c|c|c|c|c|c|}
\hline \multirow{4}{*}{$\begin{array}{l}\text { Inoculation } \\
\text { treatments }\end{array}$} & \multirow{4}{*}{$\begin{array}{c}\text { Salinity } \\
\text { levels of } \\
\text { irrigation } \\
\text { water } \\
\left(\mathrm{mg} \mathrm{L}^{-1}\right)\end{array}$} & \multicolumn{4}{|c|}{ Peanut cultivars } \\
\hline & & \multicolumn{2}{|c|}{ Giza 6 cultivar } & \multicolumn{2}{|c|}{ Gregory cultivar } \\
\hline & & \multicolumn{4}{|c|}{ Dehydrogenase activity and its RC-\% } \\
\hline & & $\begin{array}{r}\mu g \text { formazan } \\
g^{-1} \text { soil hour }{ }^{-1}\end{array}$ & RC (\%) & $\begin{array}{l}\mu \mathrm{g} \text { formazan } \\
\mathrm{g}^{-1} \text { soil hour }\end{array}$ & $\mathrm{RC}(\%)$ \\
\hline \multirow{3}{*}{ Control } & Nil water & 109.9 & 0 & 131.7 & 0 \\
\hline & 1000 & 89.4 & 0 & 90.8 & 0 \\
\hline & 2000 & 68.1 & 0 & 73.3 & 0 \\
\hline \multicolumn{2}{|c|}{ Mean } & 89.13 & & 98.60 & \\
\hline \multirow{3}{*}{$\begin{array}{l}\text { Solid } \\
\text { Brady }\end{array}$} & Nil water & 132.5 & 20.5 & 148.4 & 12.7 \\
\hline & 1000 & 101.5 & 13.6 & 115.6 & 27.3 \\
\hline & 2000 & 75.3 & 10.5 & 80.1 & 9.3 \\
\hline \multicolumn{2}{|c|}{ Mean } & 103.10 & & 114.70 & \\
\hline \multirow{3}{*}{$\begin{array}{l}\text { Liquid } \\
\text { Brady }\end{array}$} & Nil water & 147.3 & 34 & 162.8 & 23.6 \\
\hline & 1000 & 114.7 & 28.3 & 123.4 & 36 \\
\hline & 2000 & 82.8 & 21.6 & 87.6 & 19.5 \\
\hline \multicolumn{2}{|c|}{ Mean } & 114.93 & & 124.60 & \\
\hline \multirow{3}{*}{$\begin{array}{c}\text { Solid } \\
\text { Brady + Azo }\end{array}$} & Nil water & 170.9 & 55.5 & 204.3 & 55.1 \\
\hline & 1000 & 130.2 & 45.6 & 135.6 & 49.3 \\
\hline & 2000 & 95.7 & 40.5 & 112.8 & 53.9 \\
\hline \multicolumn{2}{|c|}{ Mean } & 132.27 & & 150.90 & \\
\hline \multirow{3}{*}{$\begin{array}{l}\text { Liquid Brady+ } \\
\text { Azo }\end{array}$} & Nil water & 176.5 & 60.6 & 213.3 & 62 \\
\hline & 1000 & 138.4 & 54.8 & 139.7 & 53.9 \\
\hline & 2000 & 99.5 & 46.1 & 116 & 58.3 \\
\hline \multicolumn{2}{|c|}{ Mean } & 138.13 & & 156.33 & \\
\hline \multicolumn{6}{|c|}{ L.S.D. at 0.05 for treatments of: } \\
\hline \multicolumn{2}{|l|}{ Inoculation } & \multicolumn{4}{|c|}{0.663} \\
\hline \multicolumn{2}{|c|}{ Irrigation Water } & \multicolumn{4}{|c|}{0.514} \\
\hline \multicolumn{2}{|l|}{ Cultivars } & \multicolumn{4}{|c|}{0.420} \\
\hline
\end{tabular}

RC, \%): the difference between the value of a particular treatment and control, calculated as percent of that control, Brady: Bradyrhizobium spp., Azo: Azotobacter chroococcum. ${ }^{* *}=$ High Significant, N.S= Not Significant. 
Data in Table (4) denote show that, the co-inoculation treatments of Azotobacter chroococcum DSM 2286 with solid or liquid Bradyrhizobium ssp, gave the highest RC rates of the enzyme activity under the assigned experimental treatments. The rhizospheric soil of Gregory peanut cultivar plants attained higher values of RC rates of the dehydrogenase activity compared with the Giza 6 peanut cultivar plants under the assigned experimental treatments. The corresponding RC values of the dehydrogenase activity in the coinoculation treatments of Azotobacter chroococcum DSM 2286 with solid Bradyrhizobium ssp, were: 55.5, 45.6 and $40.5 \%$, and with liquid Bradyrhizobium ssp, were: $60.6,54.8$ and $46.1 \%$, for the Giza 6 peanut cultivar plants treatments, irrigated with the same three salinity levels of water, respectively. The same treatments of the co-inoculation treatments with liquid Bradyrhizobium ssp, the corresponding values of RC \% of the dehydrogenase activity for the Gregory peanut cultivar plants treatments, irrigated with the same three salinity levels of water, were: $62.0,53.9$ and $58.3 \%$, respectively.

Soil dehydrogenases are the major representatives of the oxidoreductase enzymes class (Gu et al., 2009). Among all enzymes in the soil environment, dehydrogenases are of the most important and are used as an indicator of the overall soil microbial activity (Quilchano and Marañon, 2002; Gu et al., 2009 and Salazar et al., 2011), because they occur intracellularly in all living microbial cells (Moeskops et al., 2010; Zhao, 2010 and Yuan and Yue, 2012). Moreover, they are tightly linked with microbial oxidoreduction processes (Moeskops et al., 2010). Several studies that had been conducted to evaluate the effects of controlled or irrigation-induced saline conditions on soil enzyme activities and in most of those studies the depressive effects had been reported (Rietz and Haynes, 2003). Salinity depressed enzyme activities under laboratory conditions as well as irrigation-induced salinity also detrimentally influenced soil enzyme activities (Rietz and Haynes, 2003).

\section{Seed oil content}

Data in Table (5) clear that seed oil content (\%) of Giza 6 and Gregory cultivar peanut plants, as affected by the abovementioned treatments significantly increased compared with the uninoculated plants.

However, the Gregory cultivar peanut plants achieved higher seed oil content (\%), compared with the Giza 6 cultivar peanut plants, with all treatments. The maximum values of seed oil content (\%) were: 48.23 and $51.13 \%$ for Giza 6 and Gregory cultivar peanut plants, respectively, significantly affected by the inoculation treatment of liquid Bradyrhizobium spp with Azotobacter chroococcum, as Co-inoculation, irrigated with the first salinity levels of water. The seeds oil content (\%) of Giza 6 cultivar peanut plants, under the highest salinity level of irrigation water $(2000 \mathrm{mg}$ $\mathrm{L}^{-1}$ ), were $46.62,46.98,47.07$ to $47.20 \%$ and for Gregory cultivar 47.67, 47.95, 48.44 to $48.57 \%$, with all inoculation, respectively.

The relative changes values (RC) calculated for the seed oil content of seeds of Giza 6 and Gregory cultivar peanut plants as recorded in Table (5) exhibit that, the inoculation by liquid Bradyrhizobium spp with the Azotobacter chroococcum as co inoculation treatments was associated with a highest values of "RC\%", at the different salinity levels of irrigation water. The 
corresponding values of RC, \% for seed oil content exceeded the control for both cultivar peanut plants. In generally, responses of Gregory cultivar peanut plants to inoculation treatments were higher than the Giza 6 cultivar peanut plants, under the all studied treatments. These results are in a good line with those obtained by El Habbasha, et al. (2005), who concluded that seed oil content (\%) of peanut plants were increased from 45.64 to 47.28 , by application of Bradyrhizobium spp + Azospirillum compared with uninoculated plants. In addition, El Behlak (2016) found that, Gregory cultivar peanut plants showed that the highest values of seed oil percentage $(50.15 \%)$ as compared to these recorded by Giza 6 cultivar (48.68 $\%$ by inoculation with biofertilizer "Microbein" +50 NPK mineral fertilizer.

\section{Seed protein content}

Data recorded in Table (6) demonstrated that seeds protein content of Giza 6 and Gregory cultivar peanut plants and its relative changes "RC, \%", significantly promoted by the aforesaid treatments with comparison with the uninoculated plants. Also, Co-inoculation treatments with Azotobacter chroococcum significantly augmented seed protein content more than that inoculation treatment by solid or liquid Bradyrhizobium spp alone. On the other hand, liquid Bradyrhizobium sp+ Azotobacter chroococcum gave a high seed protein content and surpassed the other inoculation treatments. Responses of seeds protein content (\%) of Gregory cultivar peanut significantly surpassed that of Giza 6 cultivar at all inoculation treatments tested, under the three salinity levels of irrigation water. Azotobacter chroococcum as Coinoculation with liquid Bradyrhizobium spp attained the high seeds protein content (\%) with values of: $24.81,22.76$ and 21.28 of Giza 6 cultivar peanut plants, under salinity levels of irrigation water, where these values were: 26.47, 25.59 and 24.05 for Gregory cultivar, under the same salinity levels of irrigation water, respectively.

Concerning the values of the RC that calculated for seeds protein content (\%) of Giza 6 and Gregory cultivar peanut plants as affected by inoculation treatments listed in Table (6) showed that, the values of $\mathrm{RC}$ of seeds protein content (\%) of Giza 6 and Gregory cultivar peanut plants appeared high responses to the inoculation with liquid Bradyrhizobium and Azotobacter chroococcum compared to the other coinoculation treatments, under the three salinity levels of irrigation water. Also, the inoculation with liquid Bradyrhizobium and Azotobacter chroococcum, resulted in raising $\mathrm{RC}$ values of seeds protein content (\%) by $34.23,27.67$ and $23.53 \%$, of the Giza 6 and $39.37,36.09$ and $31.97 \%$, of the Gregory cultivar under the three salinity levels of irrigation water, respectively. In fact, PGPRs had been shown a great effective role in improving the productivity and quality of many legumes, whenever they Co-inoculated with rhizobia. This synergistic effect may be elucidated by their ability to enhance the $\mathrm{N}_{2}$-fixation performance, as well as nutrients availability and uptake from soil, which results in the production of substances like hormones, siderophores, phosphate solubilization and improvement of nutrients and water uptake. These results are in harmony with those obtained by Abdel-Wahab et al. (2008) and Verma et al. (2014). 
H.M. El-Zemrany, et al.,

Table (5): Oil seed content (\%) of Giza 6 and Gregory cultivar peanut plants, and their $f$ relative changes values ( $\mathrm{RC}, \%)$, at harvest, as affected by inoculation and salinity levels of irrigation water.

\begin{tabular}{|c|c|c|c|c|c|}
\hline \multirow{4}{*}{$\begin{array}{l}\text { Inoculation } \\
\text { treatments }\end{array}$} & \multirow{4}{*}{$\begin{array}{l}\text { Salinity } \\
\text { levels of } \\
\text { irrigation } \\
\text { water } \\
\left(\mathrm{mg} \mathrm{L}^{-1}\right)\end{array}$} & \multicolumn{4}{|c|}{ Peanut cultivar } \\
\hline & & \multicolumn{2}{|c|}{ Giza 6 cultivar } & \multicolumn{2}{|c|}{ Gregory cultivar } \\
\hline & & \multicolumn{4}{|c|}{ Seed oil content (\%) } \\
\hline & & Oil \% & RC (\%) & Oil \% & RC (\%) \\
\hline \multirow{3}{*}{ Control } & Nil water & 46.74 & 0.00 & 48.39 & 0.00 \\
\hline & 1000 & 46.71 & 0.00 & 48.08 & 0.00 \\
\hline & 2000 & 46.23 & 0.00 & 46.99 & 0.00 \\
\hline \multicolumn{2}{|c|}{ Mean } & 46.56 & & 47.82 & \\
\hline \multirow{3}{*}{$\begin{array}{l}\text { Solid } \\
\text { Brady }\end{array}$} & Nil water & 47.5 & 1.62 & 49.59 & 2.49 \\
\hline & 1000 & 47.18 & 1.01 & 48.69 & 1.27 \\
\hline & 2000 & 46.62 & 0.85 & 47.67 & 1.46 \\
\hline \multicolumn{2}{|c|}{ Mean } & 47.10 & & 48.65 & \\
\hline \multirow{3}{*}{$\begin{array}{l}\text { Liquid } \\
\text { Brad }\end{array}$} & Nil water & 47.69 & 2.04 & 49.76 & 2.84 \\
\hline & 1000 & 47.58 & 1.85 & 48.96 & 1.84 \\
\hline & 2000 & 46.98 & 1.63 & 47.95 & 2.04 \\
\hline \multicolumn{2}{|c|}{ Mean } & 47.42 & & 48.89 & \\
\hline \multirow{3}{*}{$\begin{array}{c}\text { Solid } \\
\text { Brady + Azo }\end{array}$} & Nil water & 47.89 & 2.46 & 50.14 & 3.61 \\
\hline & 1000 & 47.67 & 2.07 & 49.5 & 2.96 \\
\hline & 2000 & 47.07 & 1.82 & 48.44 & 3.08 \\
\hline \multicolumn{2}{|c|}{ Mean } & 47.54 & & 49.36 & \\
\hline \multirow{3}{*}{$\begin{array}{l}\text { Liquid Brady+ } \\
\text { Azo }\end{array}$} & Nil water & 48.23 & 3.19 & 51.13 & 5.67 \\
\hline & 1000 & 47.94 & 2.63 & 49.57 & 3.1 \\
\hline & 2000 & 47.2 & 2.1 & 48.57 & 3.37 \\
\hline \multicolumn{2}{|c|}{ Mean } & 47.79 & & 49.76 & \\
\hline \multicolumn{6}{|c|}{ L.S.D. at 0.05 for treatments of: } \\
\hline \multicolumn{2}{|l|}{ Inoculation } & \multicolumn{4}{|c|}{0.402} \\
\hline \multicolumn{2}{|l|}{ Irrigation Water } & \multicolumn{4}{|c|}{ N.S } \\
\hline \multicolumn{2}{|l|}{ Cultivars } & \multicolumn{4}{|c|}{0.254} \\
\hline
\end{tabular}

RC, \%): the difference between the value of a particular treatment and control, calculated as percent of that control, Brady: Bradyrhizobium spp., Azo: Azotobacter chroococcum. $\quad{ }^{* *}=$ High Significant, N.S= Not Significant. 
Table (6): Protein seed content (\%) and their rate of relative changes (RC, \%) of Giza 6 and Gregory cultivar peanut plants, at harvest as affected by inoculation and salinity levels of irrigation water.

\begin{tabular}{|c|c|c|c|c|c|}
\hline \multirow{4}{*}{$\begin{array}{l}\text { Inoculation } \\
\text { treatments }\end{array}$} & \multirow{4}{*}{$\begin{array}{c}\text { Salinity levels } \\
\text { of irrigation } \\
\text { water } \\
\left(\mathrm{mg} \mathrm{L^{-1 } )}\right.\end{array}$} & \multicolumn{4}{|c|}{ Peanut cultivar plants } \\
\hline & & \multicolumn{2}{|c|}{ Giza 6 cultivar } & \multicolumn{2}{|c|}{ Gregory cultivar } \\
\hline & & \multicolumn{4}{|c|}{ Seed protein content (\%) } \\
\hline & & Protein \% & RC (\%) & Protein \% & RC (\%) \\
\hline \multirow{3}{*}{ Control } & Nil water & 18.48 & 0.00 & 18.99 & 0.00 \\
\hline & 1000 & 17.83 & 0.00 & 18.8 & 0.00 \\
\hline & 2000 & 17.23 & 0.00 & 18.22 & 0.00 \\
\hline \multicolumn{2}{|c|}{ Mean } & 17.85 & & 18.67 & \\
\hline \multirow{3}{*}{ 응 중 } & Nil water & 22.76 & 23.16 & 25.33 & 33.38 \\
\hline & 1000 & 20.92 & 17.33 & 22.68 & 20.62 \\
\hline & 2000 & 19.56 & 13.52 & 21.13 & 15.99 \\
\hline \multicolumn{2}{|c|}{ Mean } & 21.08 & & 23.05 & \\
\hline \multirow{3}{*}{ 믈 흄 } & Nil water & 23.19 & 25.49 & 25.96 & 36.69 \\
\hline & 1000 & 21.73 & 21.9 & 23.79 & 26.56 \\
\hline & 2000 & 19.69 & 14.28 & 21.82 & 19.77 \\
\hline \multicolumn{2}{|c|}{ Mean } & 21.54 & & 23.86 & \\
\hline \multirow{3}{*}{ 응 훙 웅 } & Nil water & 23.55 & 27.45 & 25.98 & 36.82 \\
\hline & 1000 & 22.44 & 25.86 & 24.97 & 32.84 \\
\hline & 2000 & 20.22 & 17.35 & 23 & 26.26 \\
\hline \multicolumn{2}{|c|}{ Mean } & 22.07 & & 24.65 & \\
\hline \multirow{3}{*}{ 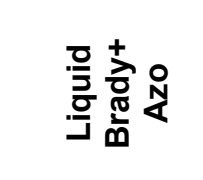 } & Nil water & 24.81 & 34.23 & 26.47 & 39.37 \\
\hline & 1000 & 22.76 & 27.67 & 25.59 & 36.09 \\
\hline & 2000 & 21.28 & 23.53 & 24.05 & 31.97 \\
\hline \multicolumn{2}{|c|}{ Mean } & 22.95 & & 25.37 & \\
\hline \multicolumn{6}{|c|}{ L.S.D. at 0.05 for treatments of: } \\
\hline \multicolumn{2}{|l|}{ Inoculation } & \multicolumn{4}{|c|}{0.955} \\
\hline \multicolumn{2}{|c|}{ Irrigation Water } & \multicolumn{4}{|c|}{ N.S } \\
\hline \multicolumn{2}{|l|}{ Cultivars } & \multicolumn{4}{|c|}{0.604} \\
\hline
\end{tabular}

RC, \%): the difference between the value of a particular treatment and control, calculated as percent of that control. ${ }^{* *}$ Brady: Bradyrhizobium spp. ${ }^{* *}$ Azo: Azotobacter chroococcum. N.S= Not significant 


\section{REFERENCES}

Abdel-Wahab, A.F.M., G.A.A. Mekhemar, F.Sh.F. Badawi and Heba Sh. Shehata (2008). Enhancement of nitrogen fixation, growth and productivity of Bradyrhizobium-lupin symbiosis via co-inoculation with rhizobacteria in different soil types. J. Agric. Sci., Mansoura Univ. 33: 469-484.

AOAC. (2000). Official Methods of Analysis of AOAC International.17th edition by Horwitz, W. Suite (ed.), Vol.2, chapter (41): 2200 p.

Atlas, R. M. (1995). "Handbook of Media for Environmental Microbiology". CRC Press, Boca Raton, FL.

Badawi, F.Sh.F., A.M.M. Biomy and A.H. Desoky (2011). Peanut plant growth and yield as nluencedby coinoculation with Bradyrhizobium and some rhizo- microorganisms under sandy loam soil conditions. Annals of Agri. Sci., 56: 17-25.

Chaudhary, D. and S.S. Sindhu (2015). Inducing salinity tolerance in chickpea (Cicer arietinum L.) by inoculation of 1-aminocyclopropane-1-carboxylatedeaminasecontaining Mesorhizobium strains. Afr. J. Microbiol. Res. 9: 117124.

Cottenie, A., M. Verloo, L. Kiekens, G. Velghe and R. Amertynck (1982). Chemical analysis of plants and soils. Laboratory of Analytical and Agrochemistry State University, Ghent, Belgium. Pp.50-70.

Dunlap, J.R. and M.L. Binzel (1996). NaCl reduces indole- 3-acetic acid levels in the roots of tomato plants independent of stress-induced abscisic acid. Plant Physiol., 112: 379384.

EI Behlak, SM. (2016). Use of organic and mineral fertilization for improving peanut production in sandy soils. M.Sc. Thesis In Agric. Sci. (Agronomy), Fac. Agric., Cairo Univ.
El Habbasha, S.F., A.A. Kandil, N.S. AbuHngaza, AK. Abdel-Haleem, M.A. Khalafallah and T. G. Behiary (2005). Effect of phosphorus levels and some biofertilizers on dry matter, yield and yield attributes of groundnut, Bull. Fac. Agric. Cairo Univ., 56: 237-252.

El Zemrany, H.M., M.M. El-Shinnawi, E.A. Abou Husssien and BA. Abdel-Whab (2015). Evaluation of certain local bacterial strains as diazotrophs for wheat plants. Minufiya J. Agric. Res. 40 (Part 2): 263-278.

Fageria, N. K., V. C. Ballgar and C. A. Johnes (1997). "Growth and Mineral Nutrition of Field Crops". 2nd ed. p. 494. Marcel Dekker. Inc, New York, U.S.A.

FAO Yearbook (2017). Food and Agriculture Organization of the United Nations (FAO): STATISTICAL PROGRAMME OF WORK 2016-2017. www.fao.org/publications: publications-sales@fao.org.

Gu, Y., P. Wag and C. Kong (2009). Urease, Invertase, Dehydrogenase and Polyphenoloxidase Activities in Paddy Soils Influenced by Allelophatic Rice variety. European Journal of Soil Biology, 45: 436-441.

Kang, S.M., R. Radhakrishnan, A.L. Khan, M. J. Kim, J. M. Park, B.R. Kim, D. H. Shin and I.J. Lee (2014b). Gibberellin secreting rhizobacterium, Pseudomonas putida H-2- 3 modulates the hormonal and stress physiology of soybean to improve the plant growth under saline and drought conditions. Plant Physiol. Biochem., 84: 115-124.

Kang, S.M., R. Radhakrishnan and I.J. Lee (2015). Bacillus amyloliquefaciens subsp. plantarum GR53, a potent biocontrol agent resists Rhizoctonia disease on Chinese cabbage through hormonal and antioxidants regulation. 
World J. Microbiol. and Biotec., 31 (10): 1517-1527.

Klute, A. (1986). Methods of Soil Analysis, Part 2: Physical and Mineralilogical Properties. Amer. Soc. Agron. Inc. Madison, Wise., USA.

Liu, F., S. Xing, H. Ma, Z. Du and B. Ma (2013). Cytokinin-producing, plant growth-promoting rhizobacteria that confer resistance to drought stress in Platycladus orientalis container seedlings. Appl. Microbiol. Biotechnol., 97: 9155-9164.

Lopez-Gomez, M., L. Cobos-Porras, J. Hidalgo-Castellanos and C. Lluch (2014a). Occurrence of polyamines in root nodules of Phaseolus vulgaris in symbiosis with Rhizobium tropici in response to salt stress. Phytochem., 107: 32-41. http://dx.doi.org/10.1016/ j.phytochem.2014.08.017.

Lopez-Gomez, M., J. Hidalgo-Castellanos, C. Iribarne and C. Lluch (2014b). Proline accumulation has prevalence over polyamines in nodules of Medicago sativa in symbiosis with Sinorhizobium meliloti during the initial response to salinity. Plant Soil, 374: 149-159. http://dx.doi.org/10.1007/ s11104-013-1871-1.

Mekhemar, G.A.A., F.M. Ismail, F.Sh.F. Badawi and B.A.A. Kandil (2007). Response of Peanut (Arachis hypogaea L.) to co-inoculation with Bradyrhizobium spp. and phosphate dissolving bacteria under different levels of phosphorus fertilization in sandy soils. Agric. Res. J., Suez Canal Univ. 7 (1): 1-8.

Moeskops, B., D. Buchan, S. Sleutel, L. Herawaty, E. Husen, R. Saraswati, D. Setyorini and S. De Neve (2010). Soil Microbial Communities and Activities Under Intensive Organic and Conventional Vegetable Farming In West Java, Indonesia. Applied Soil Ecology, 45: 112-120.
Munoz, N., M.E. Soria-Diaz, M. Manyani, R.C. Sanchez-Matamoros, A.G. Serrano, M. Megias and R. Lascano (2014). Structure and biological activities of lipochitooligosaccharide nodulation signals produced by Bradyrhizobium japonicum USDA 138 under saline and osmotic stress. Biology and Fertility of Soils, 50 (2): 207-215.

Numan, M., S. Bashir, Y. Khan, R. Mumtaz, Z.K. Shinwari, A. L. Khan, A. Khan and A. AL. Harrasi (2018). Plant growth promoting bacteria as an alternative strategy for salt tolerance. Microb. Res., 209: 21-32.

Nunkaew, T., D. Kantachote, H. Kanzaki, T. Nitoda and R.J. Ritchie (2014). Effects of 5-aminolevulinic acid (ALA)containing supernatants from selected Rhodopseudomonas palustris strains on rice growth under $\mathrm{NaCl}$ stress, with mediating effects on chlorophyll, photosynthetic electron transport and antioxidative enzymes. Elect. J. Biotechnol., 17: 19-26. http://dx.doi.org/10.1016/j.ejbt.2013.12. 004.

Palaniyandi, S.A., K. Damodharan, S.H. Yang and J.W. Suh (2014). Streptomyces sp. strain PGPA39 alleviates salt stress and promotes growth of 'Micro-Tom' tomato plants. J. Appl. Microbiol., 117: 766-773. http://dx.doi.org/10.1111/jam.12563.

Quilchano, C. and T. Marañon (2002). Dehydrogenase Activity In Mediterranean Forest Soils. Biology \& Fertility of Soils, 35: 102-107.

Ribaut, J.M. and P.E. Pilet (1994). Water stress and indol-3-acetic acid content of maize roots. Planta, 193: 502-507.

Rietz, D.N. and R.J. Haynes (2003). Effects of irrigation-induced salinity and sodicity on soil microbial activity. Soil Biol. Biochem., 35: 845-854.

Salazar, S., L. Sanchez, J. Alvarez, A. Valverde, P. Galindo, J. Igual, A. Peix 
and I. Santa- Regina (2011). Correlation among soil enzyme activities under different forest system management practices. Ecological Engineering, 37: 1123-1131.

Skujins, J. (1976). Enzymes in soil, In: McLaren A.D. and Peterson G.H. (Eds.), Soil Biochem., Marcel Dekker, Inc. New York, USA, 371-414.

Steel, R. G. D. and J. H. Torrie (1980). Principles and Procedures of Statistics. (With special Reference to the Biological Sciences.) McGraw-Hill Book Company, New York.

Tank, N. and M. Saraf (2010). Salinityresistant plant growth promoting rhizobacteria ameliorates sodium chloride stress on tomato plants. J. Plant Interact. 5: 51-58.

Tilak, K.V., N. Ranganayaki, K.K. Pal, R. De, A.K. Saxena, Nautiyal, C. Shekhar, S. Mittal, A.K. Tripathi and Tohri, B.N. (2005). Diversity of plant growth and soil health supporting bacteria. Current Sci. 89: 136-150.

Verma, J.P., J. Yadav, K.N. Tiwari and D.K. Jaiswal (2014). Evaluation of plant growth promoting activities of microbial strains and their effect on growth and yield of chickpea (Cicer arietinum L.) in India. Soil Biol. Biochem., 70: 33-37.

Verma, J.P., J. Yadav, K.N. Tiwari and V. Singh (2010). Impact of plant growth promoting rhizobacteria on crop production. Int. Agric. Res. 5: 954-983.

Vincent, J. M. (1970). A Mamual for the Practical Study of The Root Nodule Bacteria IBP 15. Black Well Scientific Publications Oxford and Edinburgh. U.K, 146p.

Yadav, P., S. Kumar, K.P. Reddy, T. Yadav and I. Murthy (2014). Oxidative Stress and Antioxidant Defense System in Plants. Plant Biotechnology 2. Studium Press LLC, USA, pp. 261281.

Yuan, B. and D. Yue (2012). Soil Microbial and Enzymatic Activities Across a Chrono sequence of Chinese Pine Plantation Development On The Loess Plateau of China. Pedosphere, 22: 112.

Zhao, Y. (2010). Auxin biosynthesis and its role in plant development. Annu. Rev. Plant Biol. 61: 49. doi: 10.1146/annurev-arplant-042809112308. 
تقييم كفاءة التلقيح المشترك بالبرادي ريزوبيوم والأزوتوباكتر كروكووكم السائلة وتأثرها

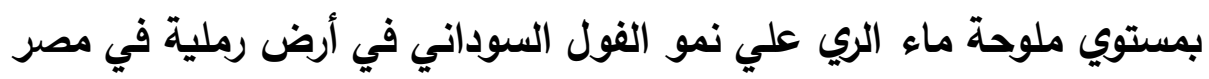

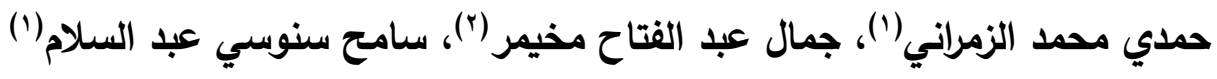

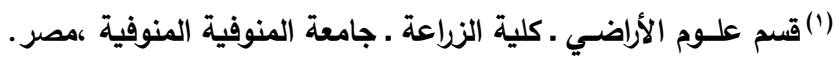

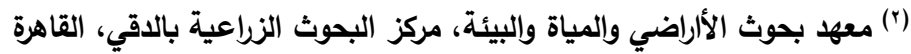

الملغص العربى بنظرة استشرافية لما هو متوقع من زيادة ملوحة مياة الآبار الإترازية في الأراضي الصحراوية المستصلحة حديثا في

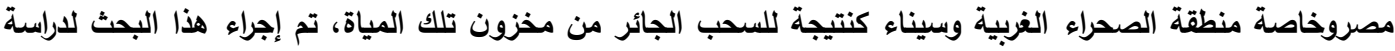

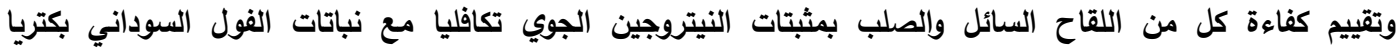

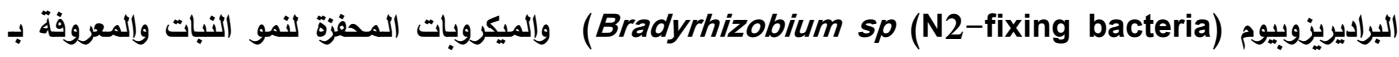
2286 Azotobacter chroococcum DSM (PGPR)

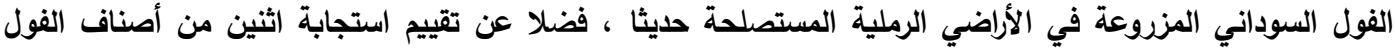

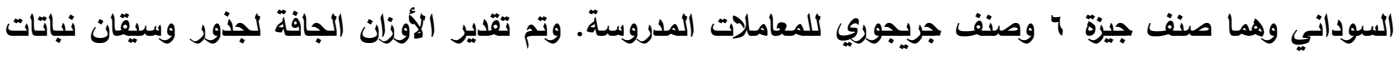

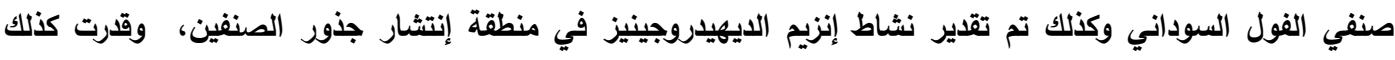

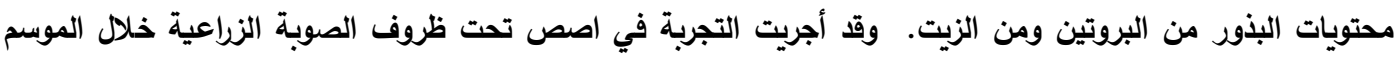

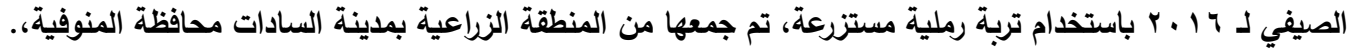

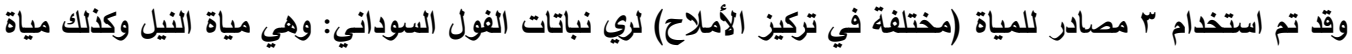

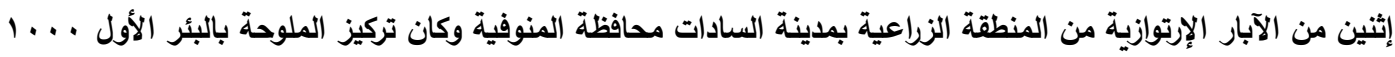

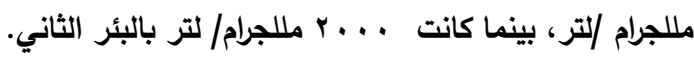

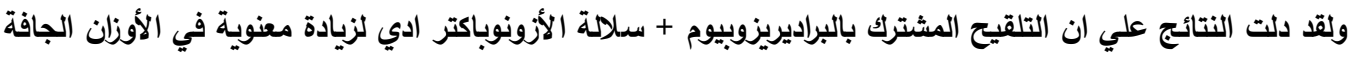

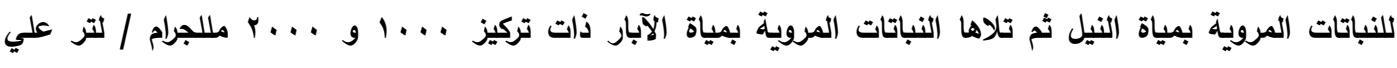

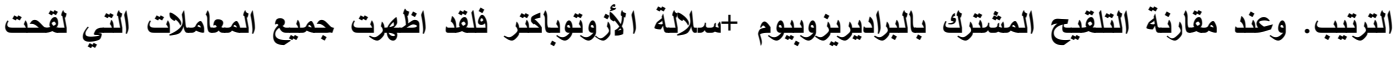

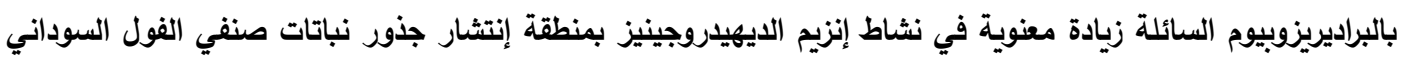

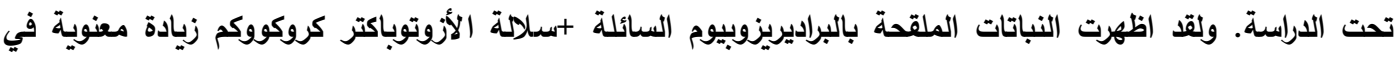

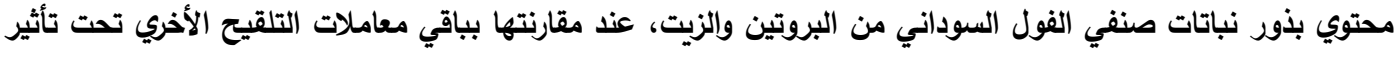
التركيزات الثلاثة لملوحة مياة الري المستخدمة في هذا البحث.

أسماء السادة المحكمين

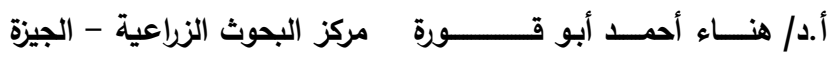

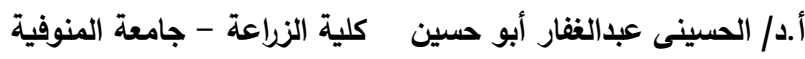

